\title{
Spatial Statistical Analysis for Potential Transit Oriented Development (TOD) in Jakarta Metropolitan Region
}

\author{
Herika Muhamad Taki ${ }^{1, *}$, Mohamed Mahmoud H. Maatouk ${ }^{1,2}$ \\ ${ }^{1}$ Department of Urban and Regional Planning, FED, King Abdulaziz University, Jeddah, 21589, Saudi Arabia \\ ${ }^{2}$ Department of Architecture, Minia University, Egypt
}

* Corresponding author : htaki0001@stu.kau.edu.sa

Tel.: +6285780173756; +966543591911

Received: Jan 11, 2018. Revised : Feb 2, 2018, Accepted: Feb 25, 2018, Published: 1 March 2018

DOI: 10.24273/jgeet.2018.3.01.1091

\begin{abstract}
Spatial planning on Transit Oriented Development (TOD) concerns with the integration between land use and transportation aspects. However, in some places, public transport management based on transit nodes such as train services which are not well- integrated, and causing spatial chaos, especially surrounding station areas. It is essential to prepare a public transportation plan by maximizing regional potential capacity with TOD model. The purpose of this paper is to identify and prioritize potential areas for TOD using spatial statistical analysis with combined models of Geographic Information System (GIS) and Analytical Hierarchy Process (AHP) for Jakarta Metropolitan Regional (JMR), Indonesia. This paper employed two major indicators: main- and sub-indicators depending on relevant references. The weight of each indicator was determined by chosen experts. The result showed that some of the metro areas of Jakarta were highly suitable for TOD and indicated the characteristics of the development of urban areas. This paper's outcome was useful in order to determine the potential location of TOD and was applicable to other areas within the same geographical conditions.
\end{abstract}

Keywords: Transit Oriented Development (TOD), Geographic Information System (GIS), Analytical Hierarchy Process (AHP), Spatial Statistical Analysis, Jakarta Metropolitan Region (JMR).

\section{Introduction}

The use of public transportation such as railway is one of the important characteristics of urban growth (Mohajeri and Amin, 2010; Taki, 2017). Many urban planning in the world relates to public service based transportation facilities that defined as compliance in the needs of present and future generations (Javadian et al., 2011; M Z Lubis et al., 2017). Moreover, rapid population growth and migration require the provision of public transport facilities as a primary need. However, in some places, the transportation management of the railway is not well integrated resulting inconveniences of city life, especially the surrounding area of the station. For example, traffic congestion, environmental pollution, unnecessary longer travel time, high fuel consumption. For this reason, it is very important to plan a public transportation such as railway that move fast by carrying maximum number of passengers to reach the maximization of the potential area (sunarto, 2009; Taki et al., 2017a). This is the part of the city development in the transportation sector, especially the renewal of stations or rail networks in accordance with the Transit Oriented Development (Binglei and Chuan, 2013; Feudo, 2014; Galelo et al., 2014).

TOD is a city development concept where attempts are made to incorporate various functional activities (mixed-use) in the area around the transit station to the extent of a pedestrian reachable radius (i.e. $\pm 400-800 \mathrm{~m}$ or equal to mileage on foot for 10 minutes). TOD has the goal of creating a green environment that is comfortable, safe, pleasant and sufficient for pedestrians (walkable environment). By mixing the various functions of the activities, the needed traveling can be combined to be shorter and faster. These functions are central to commercial areas, offices, retail, service, density to medium density as well as public open space. (Hasi buan and Soemardi, 2014) consider TOD emphasizes the integration of area-based transits, renewing individualist community and living structures.

This study has two objectives. First was to develop a method of spatial statistical analysis using AHP Techniques (Nguyen et al., 2015; Lubis et al., 2017). This approach, integrating various assessment criteria from experts including the criteria of transport facilities, urban environment, and economic performance. This research helped identify the most potential sites for TOD. Second objective was to apply this method in the context of GIS by conducting case studies in the metropolitan area of Jakarta. The spatial statistical analysis was employed to obtain a land suitability grouping for specific uses. The spatial statistical classification in one area may differ with other areas depending on the land use under 
consideration. Spatial analysis for TOD using GIS and AHP was a geographical process used to determine the feasibility of area (whether it was potential or not) for the use of TOD.

\subsection{Study Area}

Jakarta Metropolitan Region (JMR) or called Jabodetabek located in Java Island, Indonesia (Fig. 1 ). The region of JMR includes Jakarta-BogorDepok-Tangerang-Bekasi Municipality. JMR is an integrated urban area between Jakarta and its surrounding area, one of the top ten metropolitan areas in the world and the largest metropolitan area in Southeast Asia. Based on data from BPS (Statistik, 2011) shows that JMR in 2010 has a population growth of 27 million people and 7.5 million units of motor vehicles. The number of trips from Botabek to Jakarta can be quantified as much as 1.1 million trips/day. Percentage of transportation mode used: private vehicle, $62.2 \%$ (private cars and motorcycles) and public transportation $12.9 \%$ (buses and trains). The commuters from Botabek to Jakarta are highly dependent on the railway and highway network facilities.

\section{Methods}

\subsection{Data sources}

Data collected in this study derived from The Ministry of Transportation, Ministry of Agrarian and Spatial Planning, Central Bureau of Statistics,
Geospatial Information Agency. The range of data between 2010-2016 and the type of data was; First, AHP data were the primary data from interviews and questionnaires answered by 12 experts of various scientific fields related to this research for giving weight value of each indicator and subindicator. Secondary data in the form of GIS spatial data and attribute data, consisting of population statistic data, administrative boundary, land use, and transportation.

\subsection{Determination of selective criteria}

Determination of the criteria and sub criteria of the land suitability assessment for TOD was carried out by selecting and seeking for the appropriate criteria and sub criteria. It obtained from previous research and interviews by experts. These criteria and their references were; transport related (Mohajeri and Amin, 2010; Taki et al., 2017b; Atkinson-Palombo and Kuby, 2011), facilities services (Olaru et al., 2011; Ratner and Goetz, 2013; Vale, 2015), urban environment (Binglei and Chuan, 2013; Black et al., 2016; Prasertsubpakij and Nitivattananon, 2012) and economic performance (Fard, 2013; Singh et al., 2014; Taki and Lubis, 2017)

\subsection{Methodology overview}

The applied methodology was a combination of AHP and GIS technique involving the following major steps (Fig. 2):

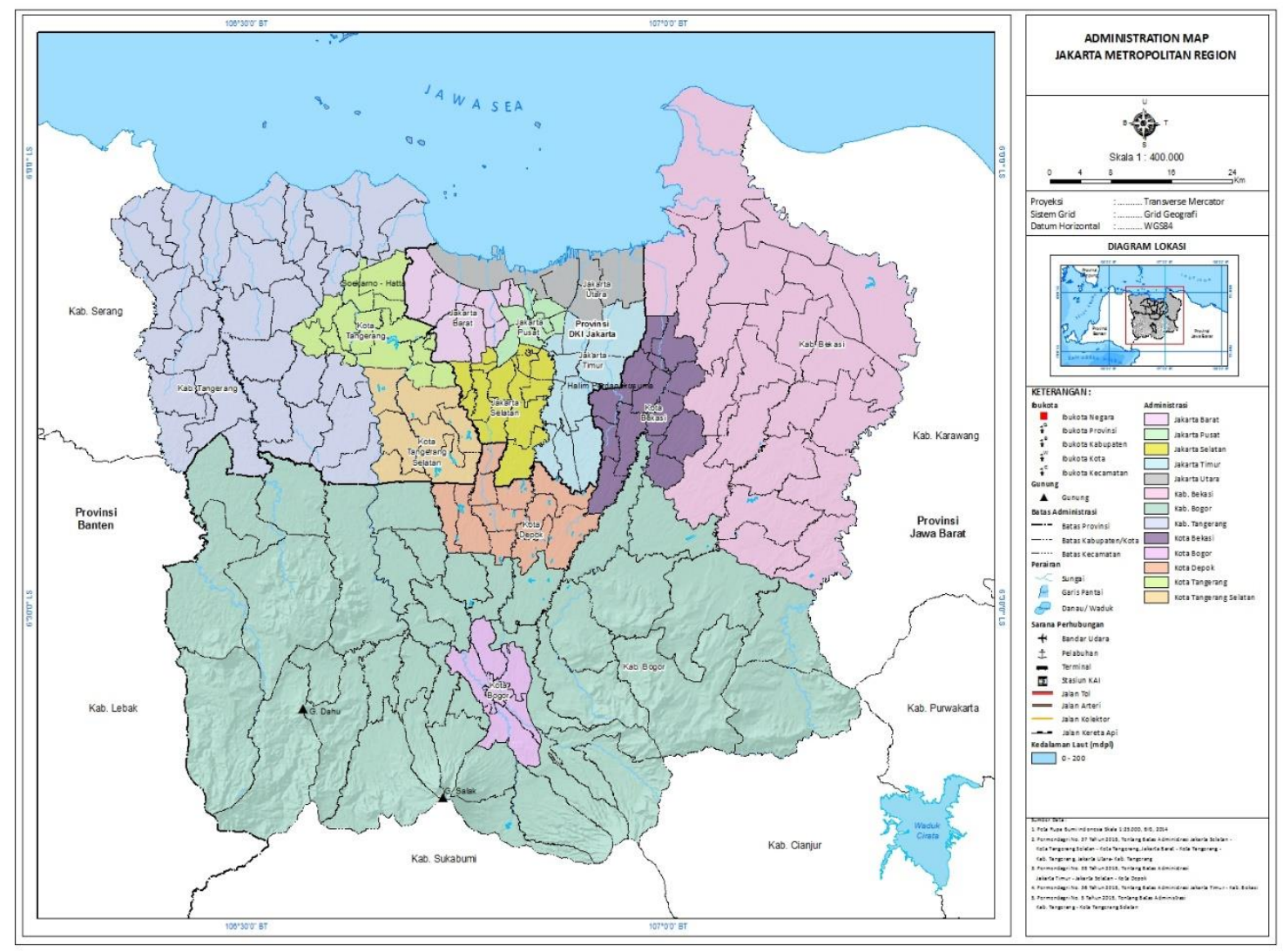

Fig. 1 The metropolitan region of Jakarta 


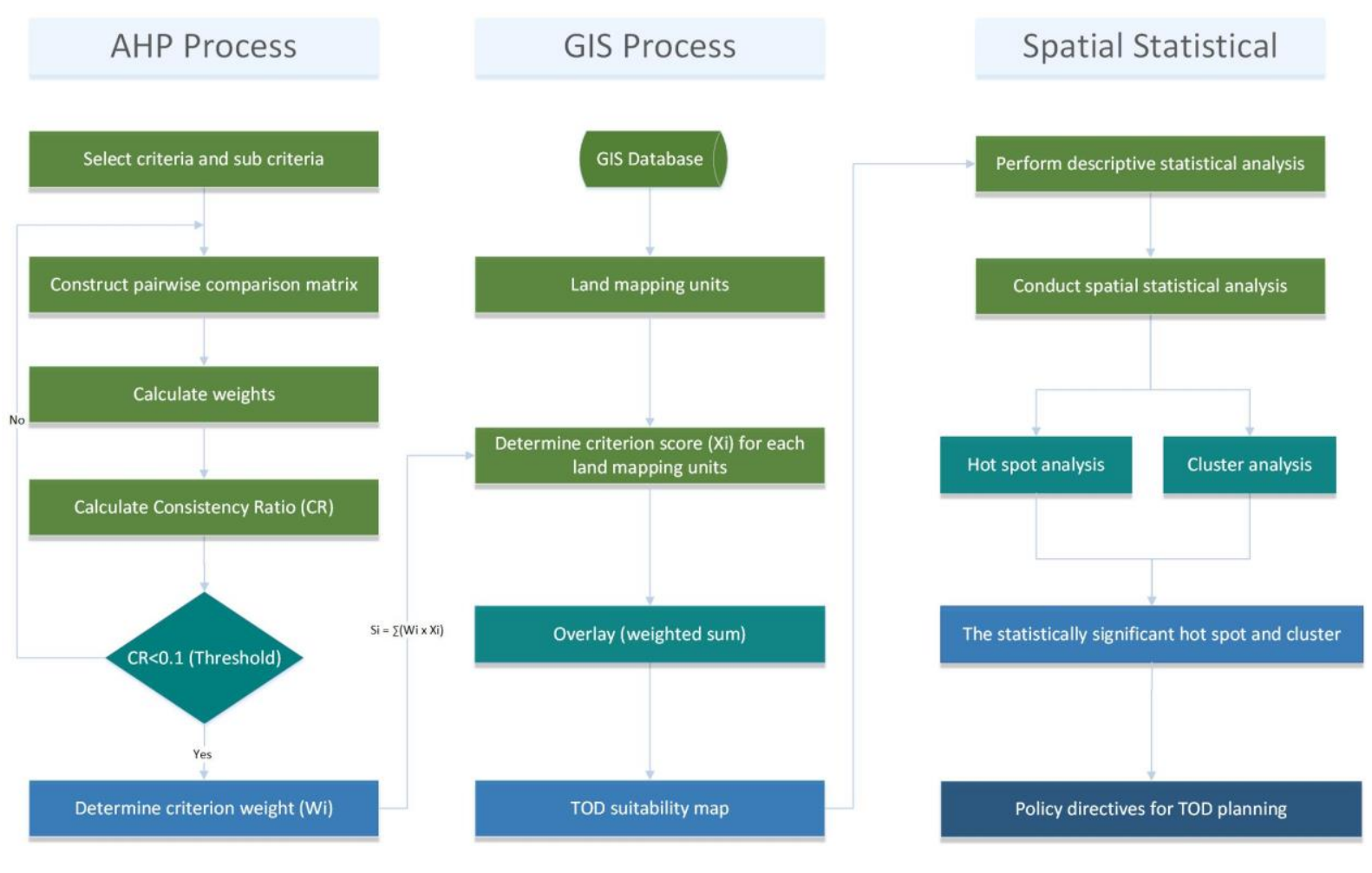

Fig. 2 Methodological framework of TOD

\subsection{AHP pairwise comparison}

AHP provides steps to ensure the credibility of relative significance used mathematically. The consistency ratio index (cr) in Equation 2 can be calculated based on the nature of the reciprocal matrix. According to Saaty (1990) that if $\mathrm{cr} \varangle 0.10$, it indicates that the matrix of pair-wise comparison has acceptable consistency. Hence, the weighting value is valid. However, if $\mathrm{cr}>0.10$, this means that the pairwise ratio shows a lack of consistency or the matrix in which it should be modified.

$c \mathrm{i}=\lambda \max -n / n-1$

Where;

$c \mathrm{i}=$ consistency index

$n=$ the number of items being compared in the matrix

$\lambda \max =$ the largest Eigen value

$c \mathrm{r}=c \mathrm{i} / r \mathrm{i}$

Where;

$\mathrm{cr}=$ consistency ratio index

$r \mathrm{i}=$ random consistency index

Table 1. $r$ i for $n=10$ (Saaty, 1990)(Saaty, 1990)

\begin{tabular}{ccccccccccc}
\hline$n$ & 1 & 2 & 3 & 4 & 5 & 6 & 7 & 8 & 9 & 10 \\
\hline$r_{\mathrm{i}}$ & 0.00 & 0.00 & 0.58 & 0.9 & 1.12 & 1.24 & 1.32 & 1.41 & 1.46 & 1.49 \\
\hline
\end{tabular}

\subsection{Standardized criteria using Z-score}

$Z$ score is a standard score of the distance of a value of the sample or population in the standard deviation unit. It is generally used to change raw scores obtained from the different types of measurements. The Z-score also tells how much distancethe score itself with mean. The formula for calculating the standard score is given on Equation 3 below:

$Z=(x-\mu) / \sigma$

Where; $\mathrm{x}=$ score, $\mu=$ mean, $\sigma=$ standard deviation

\subsection{Land suitability assessment}

Land suitability evaluation of the Food and Agriculture Organization (FAO, 1976) was adopted for land suitability assessment of potential TOD in which the FAO's classifications proposed 'appropriate' (S) and 'unsuitable (N) classes. The Equation 4 was used to combine eval uation criteria (factor) according to weighted linear combination method.

$S i=\sum_{i=1}^{n}(W i X R i)$

Where;

$\mathrm{Wi}=$ the result of multiplication of all related weights in the factor hierarchy level

$\mathrm{Ri}=$ the standard assessment of each pixel assigned to the class on the criteria map

$n=$ the number of criteria under element

\subsection{Spatial statistical analysis}

Spatial data used in this analysis are coordinated grids on the map or pixels form from 
the satellite image. Thus, the spatial statistical analysis is presented in the form of a thematic map. Spatial distribution patterns are generally divided into three groups (random, uniformed, and clustered).

2.7.1. Spatial autocorrelation analysis (Global Moran's I Statistic) for identifying existence of spatial clusters

The Moran's Index (I) is a spatial autocorrelation measurement that can be applied at intervals related to a point or area. For area data, the coefficient equation of Moran (Equation 5) is as follows:

$$
I=\frac{n \sum_{i=1}^{n} \sum_{j=1}^{n} w_{i j}\left(x_{j}-\bar{x}\right)\left(x_{j}-\bar{x}\right)}{\sum_{i=1}^{n}\left(x_{i}-\bar{x}\right)^{2}}
$$

Where, $n$ is the number of cases. $x$ is the mean of the variable. $x_{i}$ is the variable value at a particular location. $x_{x j}$ is the variable value at another location. $W_{i j}$ is a weight indexing location of $i$ relative to $j$.
2.7.2. Hot spot and outlier analysis (Getis-Ord Gi* and Anselin Local Moran's I Statistics) for mapping spatial clusters

Hot Spot Analysis (Getis-Ord Gi *) is contained in the mapping cluster set to identify statistically and formulated as Equation 6 follows:

$$
G_{i}^{*}=\frac{\sum_{j=1}^{n} w_{i j}(d) x_{j}}{\sum_{j=1}^{n} x_{j}}
$$

Where, $W_{i j}$ is a spatial weight matrix element and $(d)$ is the spatial object spacing element, while $x j$ is the attribute value for feature $j$ in distance $d$.

\section{Results}

\subsection{Classification of assessment criteria}

This study identifies the following criteria (Table 2) as an indicator of suitability assessment in the selection of potential sites for the development of TOD. The assessment for this location is based on four main-criteria and 20 subcriteria selected.

\begin{tabular}{|c|c|c|c|c|c|c|c|}
\hline \multirow{4}{*}{ Main criteria } & \multirow{4}{*}{ Sub-criteria } & \multirow{4}{*}{ Unit } & \multicolumn{5}{|c|}{ Suitable rating } \\
\hline & & & \multicolumn{3}{|c|}{ Suitable } & \multicolumn{2}{|c|}{ Not suitable } \\
\hline & & & High & Moderate & Marginal & Current & Permanent \\
\hline & & & $\mathrm{S} 1$ & S2 & S3 & N1 & $\mathrm{N} 2$ \\
\hline \multirow[t]{6}{*}{$\begin{array}{l}\text { Transportation- } \\
\text { related }\end{array}$} & $\begin{array}{l}\text { Airport and } \\
\text { Seaport }\end{array}$ & distance & $<250 \mathrm{~m}$ & $250-500 \mathrm{~m}$ & $500-800 \mathrm{~m}$ & $800-1000 \mathrm{~m}$ & $>1000 \mathrm{~m}$ \\
\hline & Terminal & distance & $<250 \mathrm{~m}$ & $250-500 \mathrm{~m}$ & $500-800 \mathrm{~m}$ & $800-1000 \mathrm{~m}$ & $>1000 \mathrm{~m}$ \\
\hline & Busway shelter & distance & $<250 \mathrm{~m}$ & $250-500 \mathrm{~m}$ & $500-800 \mathrm{~m}$ & $800-1000 \mathrm{~m}$ & $>1000 \mathrm{~m}$ \\
\hline & Main road & distance & $<250 \mathrm{~m}$ & $250-500 \mathrm{~m}$ & $500-800 \mathrm{~m}$ & $800-1000 \mathrm{~m}$ & $>1000 \mathrm{~m}$ \\
\hline & Tollgate & distance & $<250 \mathrm{~m}$ & $250-500 \mathrm{~m}$ & $500-800 \mathrm{~m}$ & $800-1000 \mathrm{~m}$ & $>1000 \mathrm{~m}$ \\
\hline & $\begin{array}{l}\text { Transportation } \\
\text { facility }\end{array}$ & distance & $<250 \mathrm{~m}$ & $250-500 \mathrm{~m}$ & $500-800 \mathrm{~m}$ & $800-1000 \mathrm{~m}$ & $>1000 \mathrm{~m}$ \\
\hline \multirow[t]{4}{*}{$\begin{array}{l}\text { Facilities } \\
\text { services }\end{array}$} & $\begin{array}{l}\text { Education and } \\
\text { public facility }\end{array}$ & ratio & $0.37-0.81$ & $0.009-0.36$ & $0.004-0.008$ & $0.01-0.003$ & 0.00 \\
\hline & $\begin{array}{l}\text { Recreation } \\
\text { facility }\end{array}$ & ratio & $0.50-0.86$ & $0.23-0.49$ & $0.05-0.22$ & $0.01-0.04$ & 0.00 \\
\hline & Hospital & distance & $<250 \mathrm{~m}$ & $250-500 \mathrm{~m}$ & $500-800 \mathrm{~m}$ & $800-1000 \mathrm{~m}$ & $>1000 \mathrm{~m}$ \\
\hline & School & distance & $<250 \mathrm{~m}$ & $250-500 \mathrm{~m}$ & $500-800 \mathrm{~m}$ & $800-1000 \mathrm{~m}$ & $>1000 \mathrm{~m}$ \\
\hline \multirow[t]{5}{*}{$\begin{array}{l}\text { Urban } \\
\text { environment }\end{array}$} & $\begin{array}{l}\text { BCR (building } \\
\text { coverage ratio) }\end{array}$ & percentage & $>80 \%$ & $61-80 \%$ & $41-60 \%$ & $20-40 \%$ & $<20 \%$ \\
\hline & Park & percentage & $2.55-9.08 \%$ & $1.26-2.54 \%$ & $0.48-1.25 \%$ & $0.12-0.47 \%$ & $0.00-0.11 \%$ \\
\hline & Planned housing & ratio & $1.23-2.32$ & $0.72-1.22$ & $0.32-0.71$ & $0.08-0.31$ & $0.00-0.07$ \\
\hline & Residential & ratio & $1.98-4.62$ & $0.92-1.97$ & $0.44-0.91$ & $0.14-0.43$ & $0.00-0.13$ \\
\hline & $\begin{array}{l}\text { FAR (floor area } \\
\text { ratio) }\end{array}$ & FAR & 4 & 3 & 2 & 1 & 0 \\
\hline \multirow[t]{5}{*}{$\begin{array}{l}\text { Economic } \\
\text { development }\end{array}$} & Population & density & $\begin{array}{l}28607- \\
49345\end{array}$ & $\begin{array}{l}14808- \\
28606\end{array}$ & $6967-14807$ & $2003-6966$ & $0-2002$ \\
\hline & $\mathrm{CBD}$ & density & 0.000001 & $\begin{array}{l}0.000001- \\
0.000000\end{array}$ & $\begin{array}{l}0.000001- \\
0.000000\end{array}$ & $\begin{array}{l}0.000001- \\
0.000000\end{array}$ & 0.000000 \\
\hline & Industrial & ratio & $4.77-8.78$ & $2.32-4.76$ & $1.05-2.31$ & $0.31-1.04$ & $0.00-0.30$ \\
\hline & $\begin{array}{l}\text { Commercial and } \\
\text { business }\end{array}$ & ratio & $0.33-0.54$ & $0.03-0.08$ & $0.09-0.18$ & $0.19-0.32$ & $0.33-0.54$ \\
\hline & Real estate & ratio & $6.90-12.91$ & $3.24-6.89$ & $1.62-3.23$ & $0.48-1.61$ & $0.00-0.47$ \\
\hline
\end{tabular}

Table 2. Classification of assessment criteria 


\subsection{Criteria maps for TOD suitability analysis}

The map of potential TOD's assessment criteria is compiled based on a GIS database of 20 subcriteria (Fig. 3-6). The process of map analysis conducted using overlay technique is to unite all layers of the map into a joined and comprehensive layer. Hence, it presents a result map that shows a potential suitability map of potential TOD in the final stage.

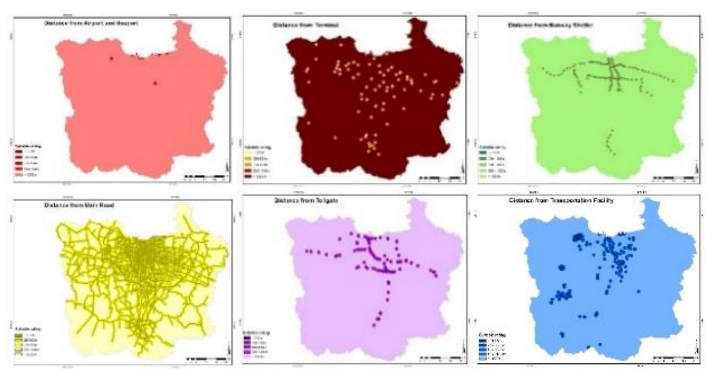

Fig. 3 Transportation-related

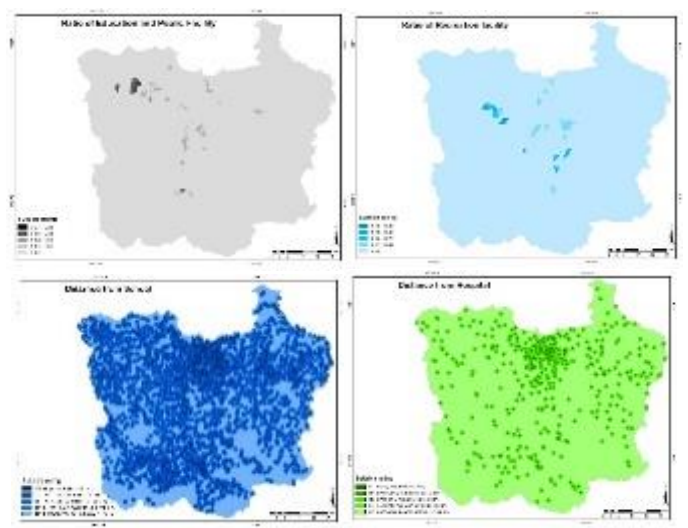

Fig. 4 Facilities services



Fig. 5 Urban environment
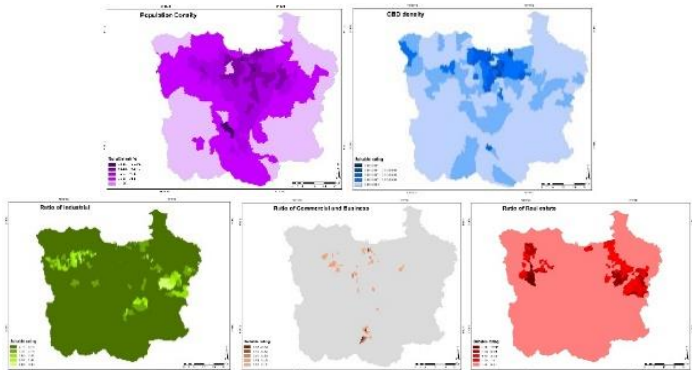

Fig. 6 Economic performance

\subsection{C alculation of criteria weight by AHP}

This study uses the opinion of experts in their fields to assess the relative importance of the selected criteria. There were 12 experts and they were required to answer and submit their opinions through a set of questionnaires, which consist of contained pairwise comparisons of the 4 main criteria and 20 sub criteria (Table 3 and 4).

Table 3. The weight of criteria from 12 experts and calculation of weight

\begin{tabular}{|c|c|c|c|c|c|c|c|c|c|c|c|c|c|c|c|c|c|c|}
\hline \multirow{2}{*}{ No } & \multirow{2}{*}{ Main-criteria } & \multirow{2}{*}{ Weight } & \multirow{2}{*}{ Sub-criteria } & \multicolumn{12}{|c|}{ Experts } & \multirow{2}{*}{ SUM } & \multirow{2}{*}{\multicolumn{2}{|c|}{ Weight Ranking }} \\
\hline & & & & E1 & E2 & E3 & E4 & E5 & E6 & E7 & E8 & E9 & E10 & E11 & E12 & & & \\
\hline \multirow{7}{*}{ I } & \multirow{7}{*}{$\begin{array}{l}\text { Transportation- } \\
\text { related }\end{array}$} & \multirow{7}{*}{0.40} & Terminal & 0.22 & 0.21 & 0.29 & 0.22 & 0.19 & 0.41 & 0.41 & 0.41 & 0.13 & 0.13 & 0.13 & 0.40 & 3.16 & 0.26 & 1 \\
\hline & & & Transportation facility & 0.09 & 0.08 & 0.14 & 0.33 & 0.32 & 0.16 & 0.16 & 0.16 & 0.41 & 0.41 & 0.41 & 0.25 & 2.89 & 0.24 & 2 \\
\hline & & & Main road & 0.12 & 0.13 & 0.14 & 0.09 & 0.10 & 0.21 & 0.21 & 0.21 & 0.11 & 0.11 & 0.11 & 0.10 & 1.65 & 0.14 & 3 \\
\hline & & & Airport and Seaport & 0.28 & 0.33 & 0.09 & 0.08 & 0.10 & 0.10 & 0.10 & 0.10 & 0.15 & 0.15 & 0.15 & 0.12 & 1.74 & 0.14 & 4 \\
\hline & & & Busway shelter & 0.18 & 0.15 & 0.24 & 0.17 & 0.16 & 0.07 & 0.07 & 0.07 & 0.13 & 0.13 & 0.13 & 0.07 & 1.58 & 0.13 & 5 \\
\hline & & & Tollgate & 0.11 & 0.11 & 0.11 & 0.12 & 0.14 & 0.05 & 0.05 & 0.05 & 0.07 & 0.07 & 0.07 & 0.06 & 0.98 & 0.08 & 6 \\
\hline & & & inconsistency & 0.09 & 0.09 & 0.08 & 0.08 & 0.09 & 0.03 & 0.03 & 0.03 & 0.06 & 0.06 & 0.06 & 0.09 & & & \\
\hline \multirow{6}{*}{ II } & \multirow{6}{*}{$\begin{array}{l}\text { Economic } \\
\text { development }\end{array}$} & \multirow{6}{*}{0.31} & Population density & 0.45 & 0.41 & 0.34 & 0.40 & 0.29 & 0.46 & 0.46 & 0.46 & 0.44 & 0.44 & 0.44 & 0.23 & 4.82 & 0.40 & 1 \\
\hline & & & CBD & 0.35 & 0.24 & 0.25 & 0.27 & 0.18 & 0.25 & 0.25 & 0.25 & 0.21 & 0.21 & 0.21 & 0.19 & 2.85 & 0.23 & 2 \\
\hline & & & Industrial & 0.14 & 0.11 & 0.14 & 0.20 & 0.33 & 0.15 & 0.15 & 0.15 & 0.18 & 0.18 & 0.18 & 0.23 & 2.15 & 0.17 & 3 \\
\hline & & & Commercial and business & 0.23 & 0.19 & 0.18 & 0.05 & 0.08 & 0.07 & 0.07 & 0.07 & 0.06 & 0.06 & 0.06 & 0.13 & 1.25 & 0.10 & 4 \\
\hline & & & Real estate & 0.08 & 0.06 & 0.09 & 0.07 & 0.11 & 0.07 & 0.07 & 0.07 & 0.11 & 0.11 & 0.11 & 0.23 & 1.18 & 0.10 & 5 \\
\hline & & & inconsistency & 0.09 & 0.08 & 0.06 & 0.05 & 0.08 & 0.04 & 0.04 & 0.04 & 0.01 & 0.01 & 0.01 & 0.09 & & & \\
\hline \multirow{5}{*}{ III } & \multirow{5}{*}{$\begin{array}{l}\text { Facilities } \\
\text { services }\end{array}$} & \multirow{5}{*}{0.17} & School & 0.08 & 0.05 & 0.08 & 0.09 & 0.23 & 0.59 & 0.59 & 0.59 & 0.50 & 0.50 & 0.50 & 0.24 & 4.06 & 0.34 & 1 \\
\hline & & & Education and public facility & 0.48 & 0.53 & 0.42 & 0.41 & 0.52 & 0.20 & 0.20 & 0.20 & 0.23 & 0.23 & 0.23 & 0.14 & 3.78 & 0.32 & 2 \\
\hline & & & Recreation facility & 0.25 & 0.28 & 0.33 & 0.38 & 0.16 & 0.08 & 0.08 & 0.08 & 0.08 & 0.08 & 0.08 & 0.36 & 2.26 & 0.19 & 3 \\
\hline & & & Hospital & 0.20 & 0.14 & 0.16 & 0.12 & 0.09 & 0.13 & 0.13 & 0.13 & 0.19 & 0.19 & 0.19 & 0.26 & 1.90 & 0.16 & 4 \\
\hline & & & inc & 0.05 & 0.06 & 0.08 & 0.09 & 0.06 & 0.02 & 0.02 & 0.02 & 0.01 & 0.01 & 0.01 & 0.08 & & & \\
\hline & \multirow{6}{*}{$\begin{array}{l}\text { Urban } \\
\text { environment }\end{array}$} & \multirow{6}{*}{0.13} & FAR & 0.07 & 0.11 & 0.09 & 0.49 & 0.49 & 0.48 & 0.48 & 0.48 & 0.28 & 0.28 & 0.28 & 0.48 & 4.03 & 0.34 & 1 \\
\hline & & & BCR & 0.36 & 0.33 & 0.21 & 0.31 & 0.31 & 0.10 & 0.10 & 0.10 & 0.11 & 0.11 & 0.11 & 0.13 & 2.28 & 0.19 & 2 \\
\hline & & & Formal housing & 0.18 & 0.18 & 0.22 & 0.06 & 0.06 & 0.17 & 0.17 & 0.17 & 0.21 & 0.21 & 0.21 & 0.16 & 2.00 & 0.17 & 3 \\
\hline & & & Informal housing & 0.13 & 0.14 & 0.17 & 0.09 & 0.09 & 0.12 & 0.12 & 0.12 & 0.26 & 0.26 & 0.26 & 0.13 & 1.90 & 0.16 & 4 \\
\hline & & & Park & 0.26 & 0.24 & 0.31 & 0.05 & 0.05 & 0.13 & 0.13 & 0.13 & 0.13 & 0.13 & 0.13 & 0.11 & 1.78 & 0.15 & 5 \\
\hline & & & inconsistency & 0.09 & 0.09 & 0.06 & 0.09 & 0.09 & 0.07 & 0.07 & 0.07 & 0.05 & 0.05 & 0.05 & 0.01 & & & \\
\hline
\end{tabular}


Table 4. (cont.) The weight of criteria from 12 experts and calculation of weight

\begin{tabular}{|c|c|c|c|c|c|c|c|c|c|c|c|c|c|c|c|}
\hline \multirow{2}{*}{ Criteria } & \multicolumn{12}{|c|}{ Experts } & \multirow[t]{2}{*}{ SUM } & \multirow[t]{2}{*}{ Weighting } & \multirow[t]{2}{*}{ Ranking } \\
\hline & E1 & E2 & E3 & E4 & E5 & E6 & E7 & E8 & E9 & E10 & E11 & $\mathrm{E} 12$ & & & \\
\hline $\begin{array}{l}\text { Transportation- } \\
\text { related }\end{array}$ & 0.53 & 0.45 & 0.50 & 0.41 & 0.41 & 0.52 & 0.52 & 0.52 & 0.26 & 0.26 & 0.26 & 0.12 & 4.75 & 0.40 & 1 \\
\hline $\begin{array}{l}\text { Economic } \\
\text { development }\end{array}$ & 0.08 & 0.08 & 0.07 & 0.38 & 0.38 & 0.26 & 0.26 & 0.26 & 0.48 & 0.48 & 0.48 & 0.49 & 3.68 & 0.31 & 2 \\
\hline Facilities services & 0.25 & 0.27 & 0.26 & 0.12 & 0.13 & 0.14 & 0.14 & 0.14 & 0.14 & 0.14 & 0.14 & 0.18 & 2.05 & 0.17 & 3 \\
\hline Urban environment & 0.14 & 0.20 & 0.17 & 0.09 & 0.08 & 0.08 & 0.08 & 0.08 & 0.13 & 0.13 & 0.13 & 0.20 & 1.51 & 0.13 & 4 \\
\hline inconsistency & 0.08 & 0.06 & 0.06 & 0.09 & 0.05 & 0.00 & 0.00 & 0.00 & 0.00 & 0.00 & 0.00 & 0.08 & & & \\
\hline Consistency Index $\left(c_{0}\right)=$ & 0.07 & 0.06 & 0.06 & 0.08 & 0.05 & 0.00 & 0.00 & 0.00 & 0.00 & 0.00 & 0.00 & 0.07 & & & \\
\hline Random Index $(0)=$ & 0.90 & 0.90 & 0.90 & 0.90 & 0.90 & 0.90 & 0.90 & 0.90 & 0.90 & 0.90 & 0.90 & 0.90 & & & \\
\hline Consistency Ratio $(g)=$ & 0.08 & 0.06 & 0.06 & 0.09 & 0.05 & 0.00 & 0.00 & 0.00 & 0.00 & 0.00 & 0.00 & 0.08 & & & \\
\hline
\end{tabular}

\subsection{Land suitability map for potential TOD}

All criteria values were standardized by the $Z$ score method using ArcGIS Software (Fig. 7-8). Each main-criteria had a different land suitability pattern. The highest index was found in the urban environment (4.0) and the lowest index was found in transportation related (0.0033). Variations pattern of land suitability map consisted of the spread points (facilities services and urban environment), area-polygon (economic development) and line buffer (transportation related). The red color showed the altitude value of the suitability, otherwise the blue colour indicated the lowness of land suitability value.
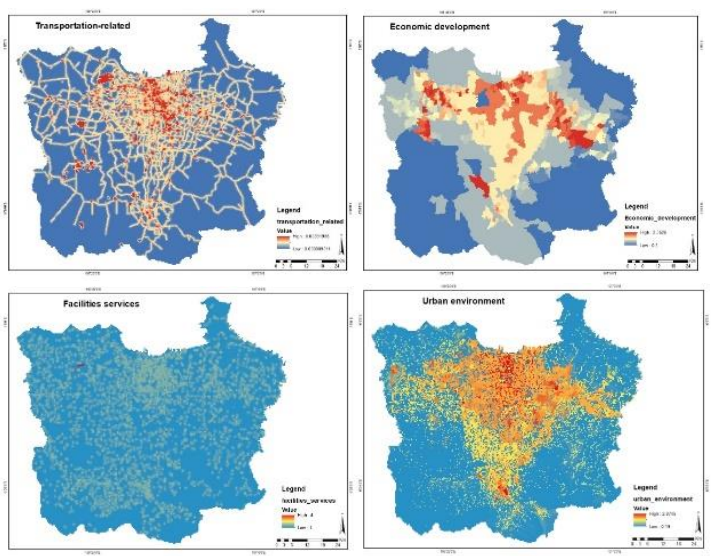

Fig. 7 Criteria map

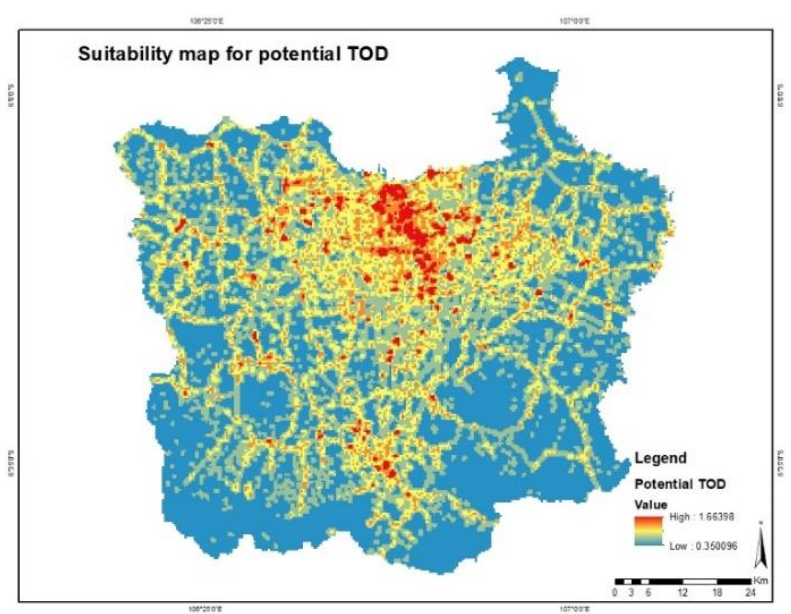

Fig. 8 Suitability map for potential TOD

\section{Discussion}

4.1. The distribution of potential TOD using suitability analysis result

Based on the suitability map (Fig. 8) of potential TOD, suitability analysis conducted a comparative class analysis based on percentage and proportion of the study area (Table 5). It is permanently not suitable class (N2) has the biggest percentage $(36,4 \%)$ with wide area about 7609.97 ha. The highly suitable class (S1) only has $2.3 \%$ of the study area with wide area about 74.69 ha. Thus, TOD planning is focused in areas with highly suitable categories. 
Table 5. The distribution of potential TOD based on percentage and area

\begin{tabular}{lccc}
\hline \multicolumn{1}{c}{ Suitable rating } & class & percentage (\%) & area (ha) \\
\hline Highly suitable & S1 & 2.3 & 174.69302 \\
\hline Moderately suitable & S2 & 9.0 & 682.65415 \\
\hline Marginally suitable & S3 & 28.1 & 2135.25561 \\
\hline Currently not suitable & N1 & 24.3 & 1847.69085 \\
\hline Permanently not suitable & N2 & 36.4 & 2769.68325 \\
\hline \multicolumn{1}{c}{ Total } & & 100 & 7609.97688 \\
\hline
\end{tabular}

\subsection{Descriptive statistical analysis}

Table 6 of descriptive statistical analysis indicated mean and standard deviation values for each main criteria and potential TOD index. The highest of mean (2.17) and standard deviation (1.04) was facilities services, while the lowest of mean (0.00) and standard deviation (0.00) was transportation related. All the indexes were positive, indicating high index value. Otherwise, there were no low negative index.

Table 6. The descriptive statistics of main criteria.

\begin{tabular}{cccccc}
\hline Statistics & $\begin{array}{c}\text { Transportation } \\
\text { related }\end{array}$ & $\begin{array}{c}\text { Economic } \\
\text { development }\end{array}$ & $\begin{array}{c}\text { Facilities } \\
\text { services }\end{array}$ & $\begin{array}{c}\text { Urban } \\
\text { environment }\end{array}$ & Potential \\
TOD
\end{tabular}

\subsection{Spatial statistical analysis}

\subsubsection{Spatial autocorrelation using Global} Moran-l

The calculation results of Global Moran's I statistic can be seen that the value of $Z$-score $=$ $4,838>Z 0.99=2.58$. Therefore, $H_{0}$ is rejected or the conclusion that there is spatial autocorrelation. The Moran Index is 0.247 in the range $0</ \leq 1$ and indicates a positive spatial autocorrelation. It concluded that inter area each other have similarity values or indicate that data in the clustered (Fig. 9).


Fig. 9 The standard normal distribution.

\subsubsection{High/low clustering using Getis-Ord General G}

Analysis result of High/Low Clustering using Getis-Ord General G shows that the Z-Score value of 19.6713 with p-value 0 . Based on the result can be stated that the spatial TOD index in the region has a global pattern or a clustering trend or highs cluster because there are no spatial clustering feature values. This happens because the $p$-value is small and statistically significant, so the value of the Z-Score becomes important. If the Z-Score is positive, it shows high value clustered in the research area (high cluster). Conversely, if the ZScore is negative, it shows low values clustered in the study area (low cluster).

\subsubsection{Cluster and Outlier using Anselin Local Moran's I}

Cluster area based on a difference Global Moran's TOD index is a measure that has not been able to show in the area where cluster occurs. Therefore, the test continues using Moran scatterplots (Fig. 10 and 11). The results show that most areas are in the LH (Low-High) and HL (HighLow) quadrant, which has a high index and is surrounded by low neighbouring areas and vice versa.

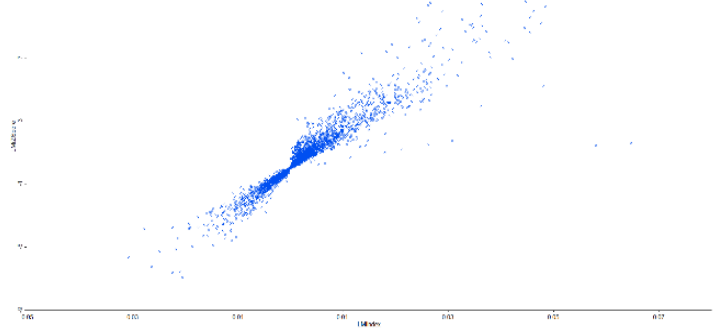

Fig. 10 Moran scatterplot

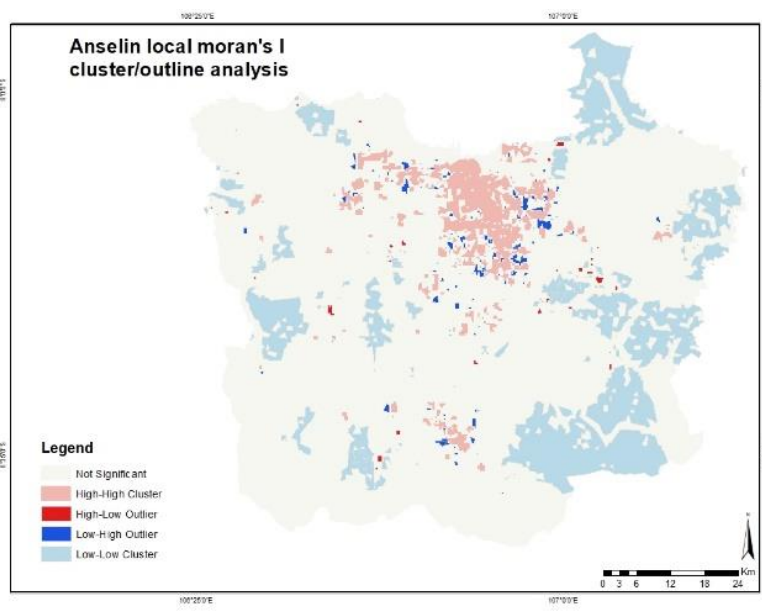

Fig. 11 Mapping cluster

\subsubsection{Hot spot and cold spot analysis using Getis-Ord Gi*}

Based on hot spot results map using Getis-Ord $\mathrm{Gi}$ * statistic in Fig. 12, there are 7 groups of interval classes in each class distribution describing distinct colour intensity levels in each color. The higher intensity of color indicates that the area has a high spatial concentration, also with the surrounding area (for areas with hot spot status), in contrast with areas that have cold spot status (blue color). 


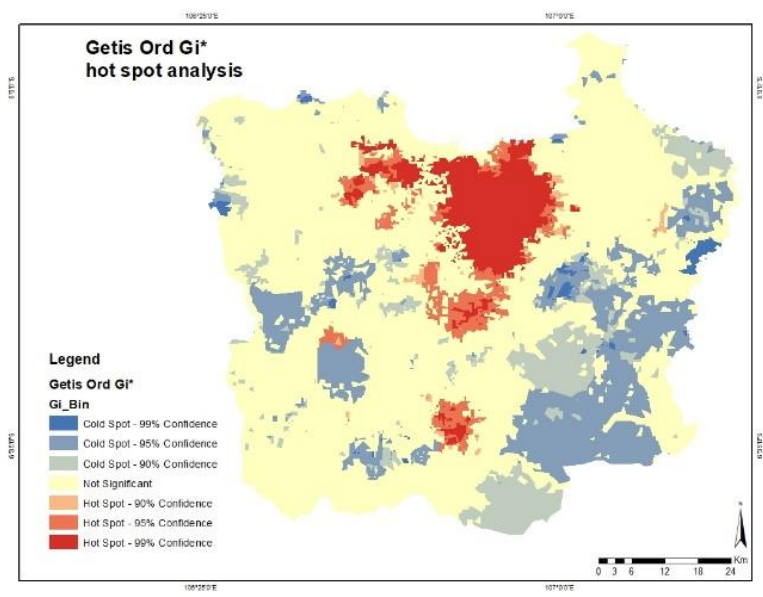

Fig. 12 Mapping hot spot

\subsubsection{The statistically significant hot spots}

Fig 13 show some areas in red color. It means that the area being the centre of the hot spot of the potential TOD index. Statistically significant hot spots have been identified at a 99\%confidence. The significant hot spots cluster in Fig 14 indicates that the area has a high value and is surrounded by high-value areas. Those areas in this cluster are the capital of Jakarta, Tangerang City, Depok City, and the city of Bogor.
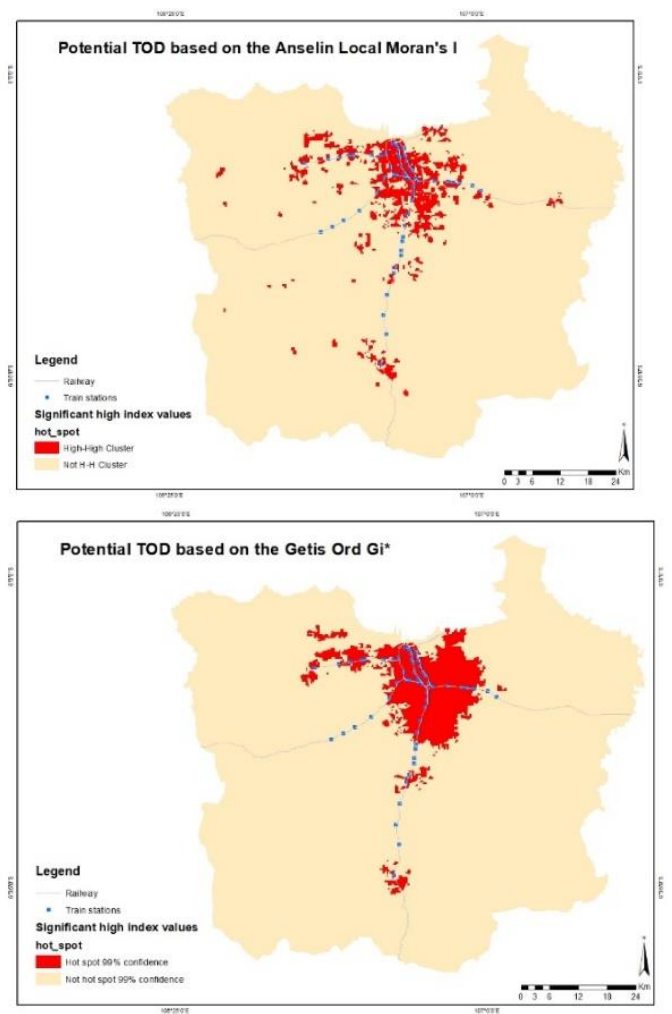

Fig. 13 Potential TOD based on Moran I (above) and Getis Gi* (below)

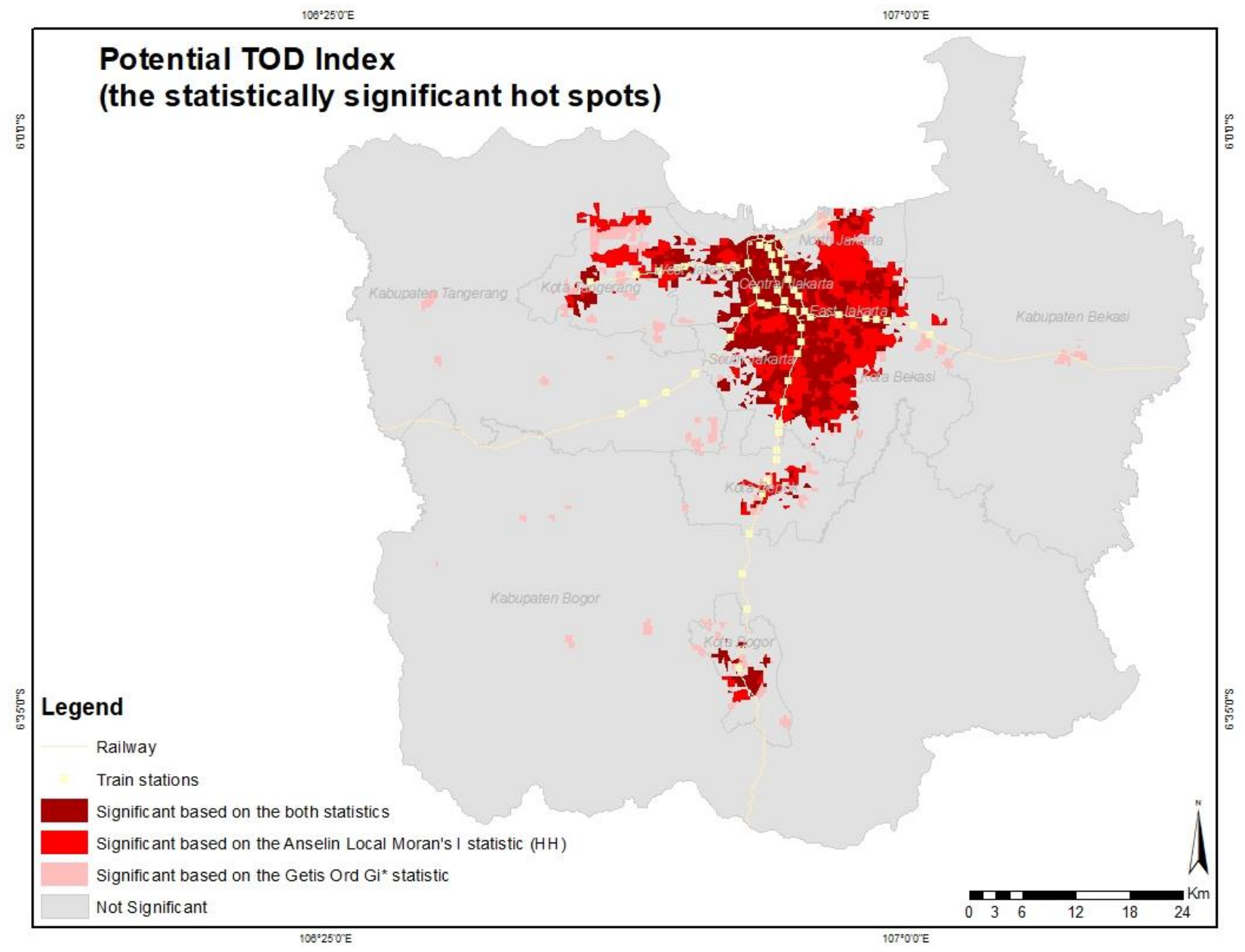

Fig. 14 Potential TOD Index based on the statistically significant hot spots 


\subsubsection{Policy directives}

In accordance with the results of the abovementioned analysis, some development directives can be compiled as an internal policy election potential area of TOD in Jakarta Metropolitan Region. First, the policy of making land zoning of each sub-district on a more detailed scale, so there should be comprehensive regulation on the land allocation to the developed area. Second, the building permit regulation/policy in areas classified as hot spots to keep the TOD area around the station from disordered land use.

\section{Conclusion}

Based on the analysis of research on spatial statistical for potential TOD area in Jakarta Metropolitan Region (JMR), it can be concluded that there is spatial regularity of TOD area class in the study area. where area with high TOD index tend to concentrate in the middle of city, while area class with low TOD index tend to show spatial spread patterns. Central JMR especially the capital of Jakarta along with Tangerang City, Depok City, and Bogor City have aTOD distribution pattern that belongs to highs cluster. The pattern of TOD distribution in the territory of the region has a strong relationship with the level of urban development and regional economy in accordance with the selected research criteria. This indicates that there is a higher development of the city and the economy of the region compared to the surrounding area. Spatial planning that can be done to organize this TOD area is by directing the arrangement of the developed region according to the allocation of land use, regulate the built area and the supporting policies contained in the regulation. The use of the spatial autocorrelation method using GIS and combined with AHP in the planning of potential areas of TOD has advantages because it can give the description of the high significancelevel and spatial clustering of hot spots among criteria to provide sharper spatial analysis.

\section{References}

Atkinson-Palombo, C., Kuby, M., 2011. The geography of advance transit-oriented development in metropolitan Phoenix, Arizona, 2000-2007. J. Transp. Geogr.

Binglei, X., Chuan, D., 2013. An Evaluation on Coordinated Relationship between Urban Rail Transit and Landuse under TOD Mode. J. Transp. Syst. Eng.

Black, J., Tara, K., Pakzad, P., 2016. Planning and Design Elements for Transit Oriented Developments/Smart Cities: Examples of Cultural Borrowings. Procedia Eng.

FAO, 1976. A framework for land evaluation, FAO soils bulletin n.32. doi:M-51

Fard, P., 2013. Measuring Transit Oriented Development: Implementing a GIS-based analytical tool for measuring existing TOD levels. Fac. GeoInformation Sci. Earth Obs. Univ. Twente.

Feudo, F., 2014. How to Build an Alternative to Sprawl and Auto-centric Development Model through a TOD
Scenario for the North-Pas-de-Calais Region? Lessons from an. Transp. Res. Procedia.

Galelo, A., Ribeiro, A., Martinez, L., 2014. Measuring and Evaluating the Impacts of TOD MeasuresSearching for Evidence of TOD Characteristics in Azambuja Train Line. Procedia-Social Behav.

Hasibuan, H., Soemardi, T., 2014. The role of transit oriented development in constructing urban environment sustainability, the case of Jabodetabek, Indonesia. Procedia Environ.

Javadian, M., Shamskooshki, H., Momeni, M., 2011. Application of Sustainable Urban Development in Environmental Suitability Analysis of Educational Land Use by Using Ahp and Gis in Tehran. Procedia Eng. $\quad 21, \quad 72-80$. doi:10.1016/j.proeng.2011.11.1989.

Lubis, M.Z, Anurogo, W., Gustin, O., Hanafi, A., Timbang, D., Rizki, F., Saragih, D.A., Kartini, I.I., Panjaitan, H.C., Yanti, M.T., 2017. Interactive modelling of buildings in Google Earth and GIS: A 3D tool for Urban Planning (Tunjuk Island, Indonesia). J. Appl. Geospatial Inf. 1, 44-48.

Lubis, M.Z., Taki, H.M., Anurogo, W., Pamungkas, D.S., Wicaksono, P., Aprilliyanti, T., 2017. Mapping the Distribution of Potential Land Drought in Batam Island Using the Integration of Remote Sensing and Geographic Information Systems (GIS), in: IOP Conference Series: Earth and Environmental Science. IOP Publishing, p. 12012

Mohajeri, N., Amin, G.R., 2010. Author's personal copy Railway station site selection using analytical hierarchy process and data envelopment analysis.

Nguyen, T.T., Verdoodt, A., Van Y, T., Del becque, N., Tran, T.C., Van Ranst, E., 2015. Design of a GIS and multicriteria based land evaluation procedure for sustainable land-use planning at the regional level. Agric. Ecosyst. Environ. doi:10.1016/j.agee.2014.10.015.

Olaru, D., Smith, B., Taplin, J., 2011. Residential location and transit-oriented development in a new rail corridor. Transp. Res. Part A Policy.

Prasertsubpakij, D., Nitivattananon, V., 2012. Evaluating accessibility to Bangkok Metro Systems using multi-dimensional criteria across user groups. IATSS Res

Ratner, K., Goetz, A., 2013. The reshaping of land use and urban form in Denver through transit-oriented development. Cities.

Saaty, T., 1990. How to make a decision: the analytic hierarchy process. Eur. J. Oper. Res.

Singh, Y., Fard, P., Zuidgeest, M., 2014. Measuring transit oriented development: a spatial multi criteria assessment approach for the City Region Arnhem and Nijmegen. J. Transp.

Statistik, B.P., 2011. Jumlah Penduduk Indonesia.

Sunarto, Retno Sari, 2009. Undelivering Service Quality in Public Transport - Case of:commuter Railway of Jabodetabek.

Taki, H., Lubis, M., 2017. Modeling accessibility of community facilities using GIS: case study of Depok City, Indonesia. J. Appl. Geospatial Inf.

Taki, H.M., 2017. Slum Revitalizing Plan of Baghdadiyah By Spatial Re-Modeling Configuration. Geoplanning J. Geomatics Plan. 0. doi:10.14710/Geoplanning.0.0.\%.

Taki, H.M., Maatouk, M.M.H., Qurnfulah, E.M., 2017a. ReAssessing TOD index in Jakarta Metropolitan Region (JMR). J. Appl. Geospatial Inf. 1, 26-35.

Taki, H.M., Maatouk, M.M.H., Qurnfulah, E.M., Aljoufie, M.O., 2017b. Planning TOD with land use and 
transport integration: a review. J. Geosci. Eng.
Environ.
Technol.
2 ,
84.

doi:10.24273/jgeet.2017.2.1.17.

Vale, D., 2015. Transit-oriented development, integration of land use and transport, and pedestrian accessibility: Combining node-place model with pedestrian shed ratio to evaluate. J. Transp. Geogr. 